\title{
Nutrient uptake in the reef-building coral Acropora palmata at natural environmental concentrations
}

\author{
John C. Bythell \\ West Indies Laboratory, Fairleigh Dickinson University, 5200 Teague Bay, Christiansted, St Croix, US Virgin Is. 00820
}

\begin{abstract}
Experiments were carried out over 15 mo to assess the net exchange of dissolved inorganic nitrogen (DIN) by the symbiotic coral Acropora palmata (Lamarck) under near-natural environmental conditions. Specimens were enclosed in situ in transparent acrylic chambers and changes in the ambient seawater concentrations of nitrate, nitrite and ammonium determined over $1 \mathrm{~h}$ closed incubations. There was a consistent depletion of nitrate and a more variable but significant mean depletion of ammonium within the experimental chambers, indicating simultaneous net uptake of both ions by the coral. No exchange of nitrite could be detected. No significant changes in concentration of any form of DIN occurred in ambient seawater control chambers. Contrary to previous predictions from studies of uptake kinetics in isolated zooxanthellae and other coral species, mean net rates of nitrate uptake exceeded that of ammonium uptake by a factor of 2. Nitrate uptake was dependent on substrate concentration, with a linear response over the range of ambient seawater concentrations encountered in the study. Rate of ammonium uptake was apparently independent of substrate concentration and the rate of uptake of each ion was independent of the concentration of the others. A diurnal rhythm was noted in nitrate uptake rates, after changes in concentration had been taken into account, which suggests that although uptake continued over the complete $24 \mathrm{~h}$ period, maximal rates of uptake were not maintained throughout the night. These results support previous studies which have demonstrated the capability for dual uptake of both nitrate and ammonium by zooxanthellae, but suggest that under natural conditions nitrate rather than ammonium provides the primary external source of dissolved inorganic nitrogen in this species.
\end{abstract}

\section{INTRODUCTION}

Waters overlying coral reefs typically contain low concentrations of dissolved nutrients (Crossland 1983) and this is seen as a primary factor limiting population development of free-living microalgae (Sournia \& Ricard 1976, Marsh 1977, Ricard 1977; but see Kinsey 1985). Zooxanthellae, the dinoflagellate symbionts associated with reef-building corals, are believed to at least partially overcome this nutrient deficiency by utilizing excretory ammonium produced by the catabolic breakdown processes of the cnidarian host (Muscatine \& Porter 1977. Muscatine 1980, Taylor 1983). Nitrogen is thereby conserved within the symbiosis and, once assimilated by the symbiont, may be returned to the host in the form of translocated amino acids (Muscatine \& Cernichiari 1969, Lewis \& Smith 1971).

In addition to internal recycling of ammonium, the zooxanthellae have also been shown to be capable of removing net quantities of ammonium and nitrate from seawater, both in the intact symbiosis (D'Elia \& Webb 1977, Muscatine \& D'Elia 1978, Webb \& Wiebe 1978, Burris 1983, Wilkerson \& Trench 1986) and in isolation (D'Elia et al. 1983). The capacity for simultaneous net uptake of both nitrate and ammonium is surprising. Nitrate uptake by microalgae is generally suppressed in the presence of significant amounts of ammonium (Syrett 1981), and zooxanthellae might be expected to be exposed to elevated tissue ammonium concentrations due to host excretion. It is possible that uptake by the zooxanthellae is so rapid as to limit ammonium concentration in the tissues or, as Szmant-Fröelich \& Pilson (1984) have suggested, reef corals may have evolved low rates of catabolism, with little ammonium production. However, the higher half-saturation constants $\left(\mathrm{K}_{\mathrm{s}}\right)$ of ammonium uptake reported for freshly isolated zooxanthellae (D'Elia et al. 1983) compared with free-living, cultured zooxanthellae (Domotor \& D'Elia 1984) would 
suggest that the zooxanthellae are indeed exposed to elevated concentrations within the tissues. Interestingly, cultured free-living zooxanthellae showed suppression of nitrate uptake when exposed to ammonium, unlike freshly isolated cells.

Little data is available on the rates of nutrient uptake at the low concentrations of nutrients occurring naturally in reef waters. Predictions of sustainable uptake rates in the natural environment based on uptake from enriched seawater (high initial nutrient concentration) are questionable. Corals may be capable of adaptive changes in uptake kinetics dependent on nutrient availability (Wilkerson \& Trench 1986). Maintaining specimens under laboratory conditions may also affect host feeding rates and excretory ammonium production (Szmant-Fröelich \& Pilson 1984).

The present study was undertaken to determine rates of dissolved inorganic nitrogen (DIN) acquisition on specimens growing under natural conditions on the reef. Experiments were repeated over a 15 mo period, and individual hour-long incubations covered the full $24 \mathrm{~h}$ day. This ensured that data represent as closely as possible the contribution of DIN uptake from seawater to growth of the coral tissue, rather than any daily or seasonal fluctuations in tissue nitrogen reserves.

\section{METHODS}

The study was carried out from the West Indies Laboratory, St Croix, US Virgin Islands $\left(17^{\circ} 45^{\prime} \mathrm{N}, 64^{\circ}\right.$ $35^{\prime} \mathrm{W}$ ). All experiments were conducted at a depth of 3 to $4 \mathrm{~m}$ in a backreef environment in Tague Bay, located at the eastern end of the island.

Net rates of DIN flux were determined by enclosing specimens in situ, for $1 \mathrm{~h}$ incubations, inside largevolume $(4.7 \mathrm{l})$ acrylic chambers. The ratio of seawater volume to live coral tissue within the chambers was ca 100:1. Turbulent water flow, approximating natural flow rates (estimated visually using dye tracers), was produced inside the chambers by $12 \mathrm{~V}$ submersible bilge pumps. These also allowed ambient seawater to be flushed through the chamber between flux determinations. Coral specimens were maintained in the field for up to several months. Small colonies, 250 to $650 \mathrm{~g}$ dry skeletal weight, were broken off at the dead base and secured to PVC tubing previously driven on to the branch of a dead, intact colony. Inside the experimental chambers the dead base was also used to secure the coral, and the live tissues of the specimen were never brought into contact with the chamber walls or handled during experiments. Experiments were repeated at approximately monthly intervals over $15 \mathrm{mo}$ and ran for $12 \mathrm{~h}$ with alternate $1 \mathrm{~h}$ closed incubations followed by $1 \mathrm{~h}$ flushing with ambient seawater.
Nutrient concentrations were determined at the start and end of the closed incubation periods from 2 replicate $100 \mathrm{ml}$ syringe samples taken from inside each chamber. Manual wet-chemical techniques were employed (Parsons et al. 1984), modified for small, 5 to $10 \mathrm{ml}$ samples. Samples were filtered immediately after collection using pre-ashed $\left(450^{\circ} \mathrm{C}, 4 \mathrm{~h}\right)$ Whatman GF/ C syringe filters. Duplicate $5 \mathrm{ml}$ subsamples of each $100 \mathrm{ml}$ sample were fixed in the field (Degobbis 1973) for ammonium analysis within $12 \mathrm{~h}$. The remaining sample was frozen within $2 \mathrm{~h}$ for nitrate and nitrite analysis within $10 \mathrm{~d}$. Flux rates were calculated from changes in chamber content and expressed as a function of surface area of the specimen, determined by the wrapped-foil technique (Marsh 1970). An ambient seawater control incubation was carried out using an identical chamber system during each experimental incubation.

Potential daily patterns in flux rate were tested for using a Fourier series regression, transforming time of day using trigonomic functions assuming a basic $24 \mathrm{~h}$ periodicity (Bliss 1970). The model employed was of the form:

$y=a+b_{1} \cos (c t)+b_{2} \sin (c t)+b_{3} \cos (2 c t)+b_{4} \sin (2 c t)$ where $\mathrm{y}=$ uptake rate; $\mathrm{c}=2 \pi / 24$ (to convert $24 \mathrm{~h}$ time units to angular units in radians); and $\mathrm{t}=$ time value from 0 to 23 . The parameters $a$ and $b_{1-4}$ were estimated using least-squares multiple regression procedures (Sokal \& Rohlf 1981).

\section{RESULTS}

Precision of the nutrient analyses, as determined from errors between duplicates, was high: $\pm 0.06 \mu \mathrm{M}$ nitrate, $\pm 0.02 \mu \mathrm{M}$ nitrite and $\pm 0.06 \mu \mathrm{M}$ ammonium ( \pm 2 standard errors; Youden 1959, D'Elia 1983). No change in concentration of ambient seawater controls could be detected over the $1 \mathrm{~h}$ incubation period (paired samples t-test on initial and final concentration; nitrate $\mathrm{p}>0.5$, nitrite $\mathrm{p}>0.2$, ammonium $\mathrm{p}>0.5, \mathrm{n}=$ 96,82 and 96 respectively).

\section{Nitrite uptake}

Seawater concentrations of nitrite were extremely low $(0.02$ to $0.19 \mu \mathrm{M})$, and there was no detectable uptake of this ion by the coral (paired t-test; $\mathrm{p}>0.2, \mathrm{n}=$ 96).

\section{Nitrate uptake}

Net uptake of nitrate occurred over the entire range of natural seawater concentrations encountered in the study ( 0.22 to $\left.1.72 \mu \mathrm{M} \mathrm{NO}_{3}\right)$, during all seasons and at 


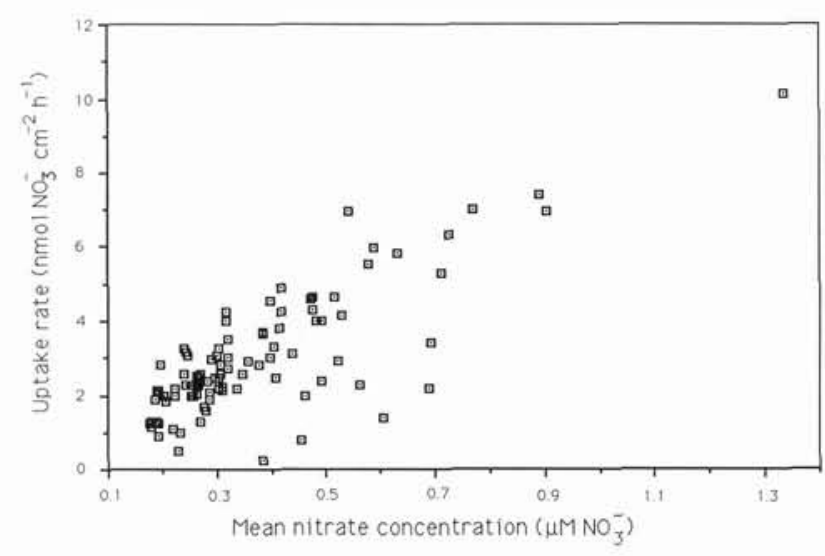

Fig. 1. Net nitrate uptake rate against concentration (Pearson correlation coefficient, $\mathrm{r}=0.80, \mathrm{p}<0.001)$. Uptake rate was standardized to specimen surface area, and concentration expressed as the mean of the initial and final levels within the experimental chamber for each incubation

all times of the $24 \mathrm{~h}$ day. There was a significant linear regression between uptake rate and ambient concentration (Fig. 1; $F=94.7,0.025>p>0.01$ ). A Lineweaver-Burke reciprocal transformation (e.g. Harlin \& Wheeler 1985) was applied in order to test for saturation uptake kinetics, but the regression was not significant $(F=11.6,0.10>p>0.05)$. It is apparent that the natural seawater concentrations encountered rarely, if ever, led to saturation of uptake systems. No correlation could be detected between nitrate uptake rate and ambient ammonium concentration ( $\mathrm{p}>0.1, \mathrm{n}=96)$.

There appeared to be a diurnal pattern in the rate of nitrate uptake (Fig. 2), although this was not significant at $p=0.05$ (1-way ANOVA, $0.10>p>0.05$ ). The residuals of the regression of uptake rate on concentration are shown in Fig. 3. This controls for the effect of ambient concentration on uptake rate, and suggests that uptake was depressed in the early morning (between ca 04:00 and 08:00 h). A cyclic effect related to time of day was tested for using a Fourier series (periodic) regression, which significantly increased the determination of variance of the regression $(F=3.78$, $0.01>p>0.005$; Sokal \& Rohlf 1981). Simultaneous $95 \%$ confidence limits were placed on the uptake rate estimate (Fig. 4), which do not overlap for the highest estimated uptake rates around 23:00 $\mathrm{h}$ and the lowest shortly after sunrise (ca 06:30 h).

Using least-squares multiple regression procedures, the net daily uptake of nitrate was estimated to be $21.5 \pm 4.23 \mu \mathrm{mol} \mathrm{NO} \mathrm{d}^{-1}$ ( $\pm 95 \%$ confidence interval) for a colony with a standard surface area of $350 \mathrm{~cm}^{2}$, at the median seawater concentration of $0.31 \mu \mathrm{M} \mathrm{NO}$. The median concentration (of initial control samples, $\mathrm{n}$ =96) was used due to the skewed distribution of these data.

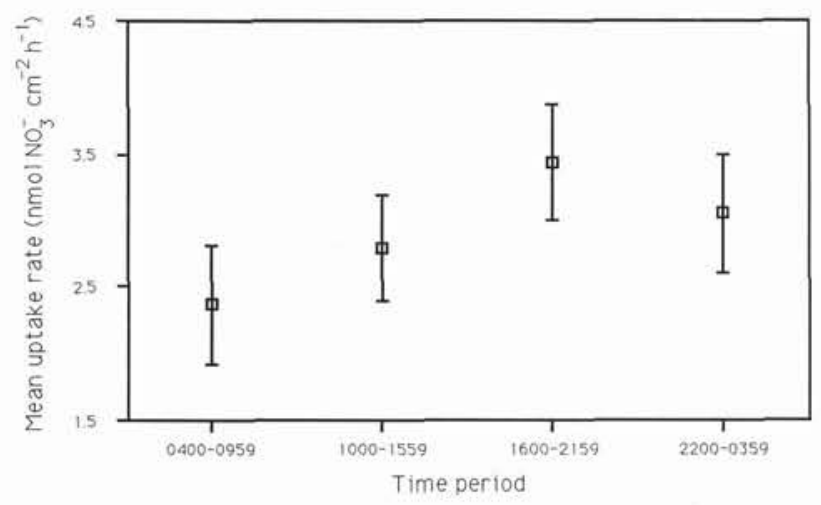

Fig. 2. Nitrate uptake rate against time of day (uptake rates standardized to specimen surface area). Mean and $\pm 95 \%$ confidence limits (Student's $\mathrm{t}_{(\mathrm{p}=0.05, \mathrm{n}-\mathrm{tdf})} \times$ standard error, $\mathrm{n}=$ $25,25,22$ and 25 for time periods $04: 00$ to $09: 59 \mathrm{~h}, 10: 00$ to $15: 59 \mathrm{~h}, 16: 00$ to $21: 59 \mathrm{~h}$ and $22: 00$ to $03: 59 \mathrm{~h}$, respectively)

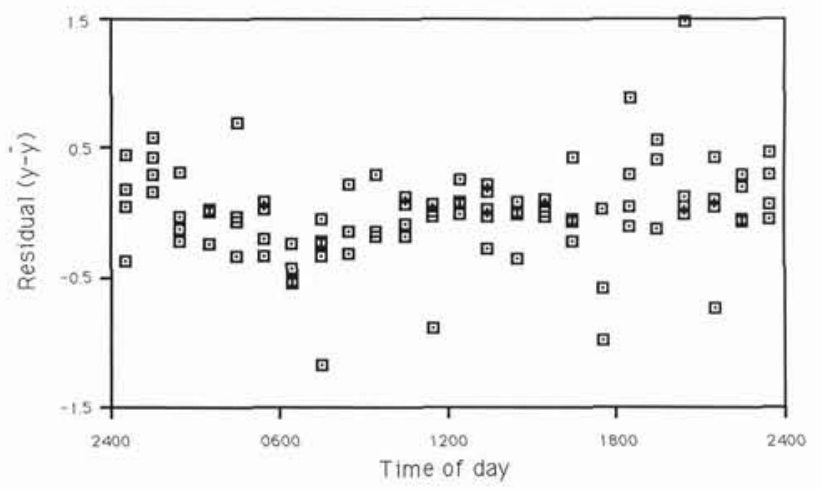

Fig. 3. Residuals ( $\mathrm{Y}-\mathrm{Y}$ estimate) from the least-squares regression of nitrate uptake rate against concentration and specimen surface area, plotted against time of day

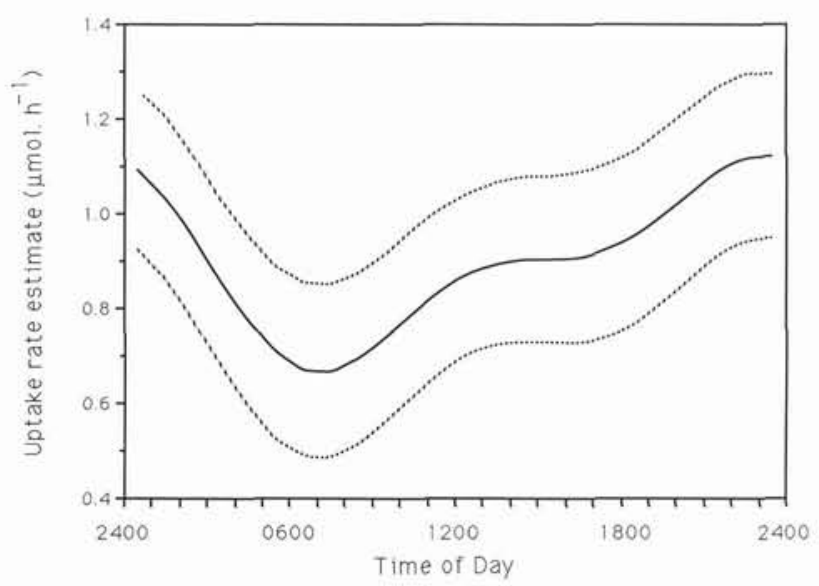

Fig. 4. Estimate of the net uptake rate for nitrate (solid line) and simultaneous $95 \%$ confidence interval (dashed lines) against time of day. Values were estimated from the multiple regression of uptake rate against concentration, specimen surface area and a 2-cycle, $24 \mathrm{~h}$ period, Fourier transformation of time of day. The hourly estimates are based on a seawater concentration of $0.31 \mu \mathrm{M}$ nitrate (the median concentration found for initial control chamber samples) and a standard specimen size of $350 \mathrm{~cm}^{2}$ surface area 


\section{Ammonium uptake}

There was a highly significant net uptake of ammonium by the coral (paired samples t-test, initial vs final concentration; $\mathrm{p}<0.001, \mathrm{n}=96$ ). However, ammonium exchange was far less consistent than was demonstrated for nitrate, with 24 out of 96 incubations showing a loss of ammonium from the specimen. Uptake rate could not be correlated with substrate ammonium concentration ( $p>0.8)$, and there appeared to be no diel or seasonal patterns in uptake rate. Since there was the possibility that the accuracy of ammonium determinations could vary between experiments, due to longer-term changes in the quality of reagents and deionized water blanks, uptake rate was examined against concentration in each experiment. No significant correlation was found in any of the 17 separate experiments. Since uptake was calculated from differences between concentration estimates, absolute accuracy is not required and, as stated earlier, precision of the determinations was high.

Daily net ammonium uptake was estimated to be $10.3 \pm 4.27 \mu \mathrm{mol} \mathrm{NH} \mathrm{NH}_{4} \mathrm{~d}^{-1}$ for the standard-sized coral specimen of $350 \mathrm{~cm}^{2}$ surface area (mean $\pm 95 \%$ confidence interval).

\section{DISCUSSION}

The capacity for simultaneous uptake of nitrate and ammonium from enriched seawater has been demonstrated for both intact corals (D'Elia \& Webb 1977. Wilkerson \& Trench 1986) and isolated zooxanthellae (D'Elia et al. 1983). This study indicates that simultaneous uptake also occurs at natural seawater concentrations. This net uptake contributes approximately $30 \%$ to the average daily nitrogen requirement for tissue growth, gamete production and dissolved organic nitrogen production (Bythell 1988).

Concentration-dependent nutrient uptake dynamics have been widely described for reef corals, although not always via Michaelis-Menten saturation uptake kinetics (Muscatine \& D'Elia 1978, Burris 1983, Wilkerson \& Trench 1986). The linear uptake kinetics found for nitrate would indicate that the coral is generally undersaturated at natural environmental concentrations $(0.22$ to $1.72 \mu \mathrm{M})$. The lack of any significant relationship between ammonium uptake rate and seawater concentration may be explained by the uptake kinetics of the zooxanthellae being masked by variability in host excretion rates and the resultant net flux between the coral and its environment. However, Muller-Parker et al. (1988) have shown uptake of ammonium by the zooxanthellae to be inhibited when isolated from well-fed sea anemones. Presumably, uptake mechanisms of the symbiont may become satu- rated as a result of ammonium excretion by the host. Ammonium uptake by natural populations of zooxanthellae may therefore be controlled largely by the feeding history of the host, rather than external concentration, unless inadequate food supplies are available. If so, present results would suggest that the coral was obtaining a significant supply of nitrogen from particulate sources.

Uptake kinetics of corals exposed to enriched seawater have led to the conclusion that ammonium is preferentially taken up over nitrate (D'Elia \& Webb 1977, Wilkerson \& Trench 1986). Perhaps due to the variable direction of ammonium flux at low concentrations, net uptake of external ammonium was found to be only approximately half that of nitrate uptake in the present study. Although ammonium may be the sole nitrogen source involved in internal recycling (between symbiont and host), nitrate must be regarded as an important, and perhaps the major, external source of nitrogen for the symbiosis.

Reef corals have previously shown no significant differences between light and dark uptake rates (Franzisket 1974, D'Elia \& Webb 1977, Burris 1983), unless they have received a period of dark preconditioning well in excess of that of the natural daily cycle (Muscatine \& D'Elia 1978, Wilkerson \& Trench 1986). This implies that an abundance of energy reserves must be available to drive uptake throughout the night. A diel pattern in nitrate uptake suggests alternatively that although sufficient energy stores are available for continued uptake throughout the night, maximal uptake rates cannot be maintained.

Although corals are able to take up nitrate in the dark, it has not been determined whether there is any direct light requirement to drive the more energydemanding processes of nitrate reduction and assimilation (Syrett 1981, Falkowski 1983). These processes are perhaps more likely to be responsible for any limitation of net uptake rates, since they have a higher energy requirement and may also be directly dependent on photochemical processes. However, the relative effects of any direct light dependence or inadequate energy supply cannot be assessed at present.

In conclusion, this study provides evidence of temporal shifts in the growth-limiting factors of the symbiosis. Simultaneous uptake of both nitrate and ammonium from low concentrations and linear uptake kinetics for nitrate across the entire natural concentration range would suggest nitrogen limitation. However, the rate of nitrogen acquisition appears to be influenced on a diel cycle, presumably due to depletion of photosynthetic products during the night. Such a mechanism could lead to time-averaged growth limitation by both photosynthetic rate and nutrient uptake rate. 
Acknowledgements. This study was funded by a NATO Overseas Studentship from the Natural Environment Research Council, UK. I thank Dr B. E. Brown and Prof. R. C. Newell for encouragement and support throughout. This is West Indies Laboratory contribution no. 192.

\section{LITERATURE CITED}

Bliss, C. I. (1970). Statistics in biology, Vol. 2. McGraw-Hill, New York

Burris, R. H. (1983). Uptake and assimilation of ${ }^{15} \mathrm{NH}_{4}^{+}$by a variety of corals. Mar. Biol. 75: 151-155

Bythell, J. C. (1988). A total nitrogen and carbon budget for the elkhorn coral Acropora plamata (Lamarck). Proc. 6th Int. Coral Reef Symp. Townsville 2: 535-540

Crossland, C. J. (1983). Dissolved nutrients in coral reef waters. In: Barnes, D. J. (ed.) Perspectives on coral reefs. Publ. 200 Aust. Inst. Mar. Sci., Townsville, p. 56-68

Degobbis, D. (1973). On the storage of seawater samples for ammonia determination. Limnol. Oceanogr. 18: 146-150

D'Elia, C. F. (1983). Nitrogen determination in seawater. In: Carpenter, E. J., Capone, D. G. (eds.) Nitrogen in the marine environment. Academic Press, New York, p. 731-762

D'Elia, C. F., Domotor, S. L., Webb, K. L. (1983). Nutrient uptake kinetics of freshly isolated zooxanthellae. Mar. Biol. 75: 157-167

D'Elia, C. F., Webb, K. L. (1977). The dissolved nitrogen flux of reef corals. Proc. 3rd Int. Coral Reef Symp. Miami 1: $326-330$

Domotor, S. L., D'Elia, C. F. (1984). Nutrient uptake kinetics and growth of zooxanthellae maintained in laboratory culture. Mar. Biol. 80: 93-101

Falkowski, P. G. (1983). Enzymology of nitrogen assimilation. In: Carpenter, E. J., Capone, D. G. (eds.) Nitrogen in the marine environment. Academic Press, New York, p. 839-868

Franzisket, L. (1974). Nitrate uptake by reef corals. Int. Rev. ges. Hydrobiol. 59:1-7

Harlin, M. M., Wheeler, P. A. (1985). Nutrient uptake. In: Littler, M. M., Littler, D. S. (eds.) Ecological field methods: macroalgae. Cambridge Univ. Press, Cambridge, p. 493-510

Kinsey, D. W. (1985). Metabolism, calcification and carbon production. I. Systems level studies. Proc. 5th Int. Coral Reef Congr., Tahiti 4: 505-526

Lewis, D. H., Smith, D. C. (1971). The autotrophic nutrition of symbiotic marine coelenterates with special reference to hermatypic corals. I. Movement of photosynthetic products between symbionts. Proc. R. Soc. Lond. B 178: 111-129

This article was submitted to the editor
Marsh, J. A. (1970). Primary productivity of reef-building calcareous red algae. Ecology 51: 255-263

Marsh, J. A., Jr (1977). Terrestrial inputs of nitrogen and phosphorus on fringing reefs of Guam. Proc. 3rd Int. Coral Reef Symp., Miami 2: 331-336

Muller-Parker, G., D'Elia, C. F., Cook, C. B. (1988). Nutrient limitation of zooxanthellae: effects of host feeding history on nutrient uptake by isolated algae. Proc. 6th Int. Coral Reef Symp., Townsville 3: 15-19

Muscatine, L. (1980). Productivity of zooxanthellae. In: Falkowski, P. G. (ed.) Primary productivity in the sea. Plenum Publ. Corp., New York, p. 381-402

Muscatine, L., Cernichiari, E. (1969). Assimilation of photosynthetic products of zooxanthellae by a reef coral. Biol. Bull. mar. biol. Lab., Woods Hole 137: 506-523

Muscatine, L., D'Elia, C. F. (1978). The uptake, retention and release of ammonium by reef corals. Limnol. Oceanogr. 23: 725-734

Muscatine, L., Porter, J. W. (1977). Reef corals: mutualistic symbioses adapted to nutrient-poor environments. Biosci. 27: $454-460$

Parsons, T. R., Maita, Y., Lalli, C. M. (1984). A manual of chemical and biological methods for seawater analysis. Pergamon Press, Oxford

Ricard, M. (1977). Phytoplankton contribution to primary productivity in two coral reef areas of Fiji Islands and French Polynesia. Proc. 3rd Int. Coral Reef Symp., Miami 1: 343-348

Sokal, R. R., Rohlf, R. J. (1981). Biometry. W. H. Freeman \& Co., New York

Sournia, A., Ricard, M. (1976). Phytoplankton and its contribution to primary productivity in two coral reef areas of French Polynesia. J. exp. mar. Biol. Ecol. 21: 129-140

Syrett, P. J. (1981). Nitrogen metabolism of microalgae. Can. Bull. Fish. Aquat. Sci. 210: 182-210

Szmant-Fröelich, A., Pilson, M. E. Q. (1984). Effects of feeding frequency and symbiosis with zooxanthellae on nitrogen metabolism and respiration of the coral Astrangia danae. Mar. Biol. 81: 153-162

Taylor, D. L. (1983). Symbioses. In: Carpenter, E. J., Capone, D. G. (eds.) Nitrogen in the marine environment. Academic Press, New York, p. 689-697

Webb, K. L., Wiebe, W. J. (1978). The kinetics and possible significance of nitrate uptake by several algal-invertebrate symbioses. Mar. Biol. 47: 21-27

Wilkerson, F. P., Trench, R. K. (1986). Uptake of dissolved inorganic nitrogen by the symbiotic clam Tridacna gigas and the coral Acropora sp. Mar. Biol. 93: 237-246

Youden, W. J. (1959). Accuracy and precision: evaluation and interpretation of analytical data. In: Kolthoff, I. M., Elving, P. J. (eds.) Treatise on analytical chemistry. Wiley, New York, p. 47-66

Manuscript first received: May 11, 1990

Revised version accepted: August 20, 1990 